\title{
Petrarch's Poetic Style from a Computational Perspective: A Digital Quantitative Approach to Italian Petrarchism
}

\author{
Jan Rohden \\ German Research Foundation (DFG), Germany \\ janrohden@gmail.com \\ (D) 0000-0001-7998-8629
}

\begin{abstract}
Few authors have shaped the history of European poetry as much as Petrarch (1304-1374). Based on its remarkable poetic style, Petrarch's most important Italian text, a collection of love poems called Canzoniere not only had an enormous impact on the poetry of his time but also became a model for centuries to come.

Scholars usually use the term "Petrarchism" to refer to Petrarch's influence on the literary landscape. Yet despite this common notion, there are still many competing approaches to defining Petrarchism. One reason for this may be the reliance of most studies of Petrarchism on a fairly small corpus of texts. While many scholars give a detailed account of Petrarch's influence on a single work or poet, only a few analyses of Petrarchism are based on a larger corpus. This may also help explain why there is still no comprehensive inventory of the stylistic or semantic elements that distinguish Petrarchism.

The goal of this essay is to take a first step towards creating such an inventory. To this end, digital methods, in particular stylometric and co-occurrence analyses, are applied to a corpus of 55 Italian poetry collections in order to determine the characteristic features of Italian Petrarchism.
\end{abstract}

\section{Petrarch, the Founder of Petrarchism}

Few authors have shaped the history of European poetry as much as Petrarch (1304-74). The reason for this lies in his varied literary works, which include a famous poetry collection in Italian entitled Canzoniere. ${ }^{1}$ Canzoniere was widely read and became an important model for love poetry in Europe over ensuing

1 Petrarch worked on this collection for many years. During that time, he changed its structure and title several times (Santagata 1992). 
centuries. Over this time, many authors also tried to imitate Petrarch's poetic style in their own texts. ${ }^{2}$

One of the factors in Canzoniere's success was the distinctive style of the collection, which consists of 366 poems about the unrequited love of the lyric's speaker ("I") for a married woman named Laura. This love, which does not end even after the woman's death, puts the speaker in highly contradictory states of mind that range from euphoria to deep sadness. This causes him suffering and creates a painful level of desire. The intermingling of suffering and desire results in a conflicted form of love for which literary researchers have proposed the term dolendi voluptas (Friedrich 1964, pp. 217-219). Dolendi voluptas is a good example of the dualities that characterise the form and content of Petrarch's collection. The poems, which take up motifs from Latin, Provençal and Italian literature, are arranged in a sequence that not only gives Canzoniere a temporal order, supported by references to specific dates and periods of the ecclesiastical year (Fornasiero 2001, pp. 59-89), but also has a narrative dimension. Petrarch's poetry collection becomes a memoir of its speaker's changing feelings for Laura, from the moment he falls in love with her at first sight to the rejection of his love described in the final poem of Canzoniere (Geyer 2009).

Petrarch's influence on his literary imitators is so far-reaching that a corresponding term has been established in the literary research: Petrarchism.

\section{Towards a Definition of Petrarchism}

Across multiple research contributions, literary scholars have identified elements they consider characteristic of Petrarch's poetic style in the texts of many European authors. In this way, they have shown his influence on European literature (Chines et al. 2006; Bernsen et al. 2011). Petrarch was particularly well received by Italian authors of the 16th century (Baldacci 1957), a trend not least illustrated by a series of poetry collections whose title, Canzoniere suggested their parallels with Petrarch's work. ${ }^{3}$

The wide-ranging impact of Petrarch's poetic approach on European literature was noted long ago by Leonard W. Forster (1963), who called Petrarchism “training in poetic diction”. More recently, Klaus W. Hempfer (1987) and Gerhard Regn (1993) have applied a systems theory perspective to describe Petrarchism as a literary system. In contrast, Rainer Warning (1987) uses Mixail Baxtin's concept of dialogicity to interpret Petrarchism as a literary appropriation of competing poetic discourses. Meanwhile Michael Bernsen understands Petrarchism as a European lingua franca that was standardised and grammaticalised in the 16th century and became a means of communication at European level (Bernsen et al. 2011, pp. 15-30).

2 Petrarch wrote another Italian-language text that had a large readership. This was Triofi, an allegorical poem in tercets. However, while Triofi deals with love, it is only one of the themes of this work, whose style was inspired by the genre of visionary literature. As such, most of the research on Petrarch's love poetry has focused on Canzoniere. The present article keeps with this tradition.

3 Collections of poems entitled Canzoniere were published by Giusto de' Conti, Angelo Galli, Lorenzo de’ Medici, Niccolò de’ Rossi and Luigi Tansillo, among others. 
These different approaches to defining Petrarchism illuminate not only the general reception of Petrarch's poetic style but also the different ways in which it has been adapted by other authors. Literary scholars have pointed out recurring elements of European literature that they believe reflect characteristics of Petrarch's poetry. Apart from dolendi voluptas, such elements include:

- Themes such as love as a form of war (Hoffmeister 1973, p. 25);

- Stylistic devices that express contrast (Friedrich 1964, p. 217);

- Glorification of the beloved in ethical and aesthetic terms (Regn 2013).

Despite these important findings, there is still no definitive typology of the distinctive elements of Petrarchan poetry. One cause of this may be the reliance of many studies of Petrarchism on a fairly small corpus of texts (see, for example, Pyritz 1963; Warning 1987; Morales Saravia 1998; Schiffer 2000). A list of these distinctive elements would, then, be valuable for the study of Petrarchism for at least two reasons: firstly, it would enable us to trace the development of specific Petrarchan features across the boundaries of individual works. Secondly, it could help us determine whether or not a text or author may be considered Petrarchan. An inventory of Petrarchan motifs is, thus, an important supplement to existing approaches to defining Petrarchism.

In order to establish such a list, we require a method that can extend beyond individual texts and be used to analyse a large corpus of poetry collections written by different authors. Quantitative digital approaches, including the contrastive analyses used in the context of stylometry, are well suited for such purposes.

\section{Contrastive Stylometric Analyses of Poetry}

Contrastive textual analysis is based on a principle of comparison: first, the textual corpus to be analysed is divided into two parts, a target and a comparison. The target is then compared with the comparison part to identify the target's overrepresented and therefore distinctive elements. To measure the distinctiveness of an element in one part, we may apply different methods or what are sometimes called distance measures. ${ }^{4}$ Within the digital humanities, two tools are often used for contrastive textual analysis: stylo for R (Eder et al. 2016) and pyzeta for Python (Schöch 2017).

In recent years, the distance measure Zeta, originally introduced by John Burrows (2007) and mathematically described by Christof Schöch (2018), has been adopted widely in the context of contrastive analysis and proven helpful for various research contributions. Based on the original measure developed by Burrows, different Zeta variants have been presented. Using an evaluation procedure, the E-Humanities junior research group Computational Literary Genre Stylistics (CLiGS) showed that different variants of Zeta can produce quite divergent results in contrastive analyses of prose texts and drama (Schöch

4 For a good introduction to contrastive text analysis, see Schöch 2018. 
et al. 2018). Regarding poetry, however, only a few contrastive analyses and no studies on the effects of different Zeta variants exist to date. ${ }^{5}$

Nevertheless in the case of Petrarchan poetry, I would suggest that contrastive stylistic analysis can certainly contribute to the scholarship. In particular, it can help us to create a comprehensive typology of distinctive motifs.

\section{Approach and Tools}

If Petrarchism refers, as its name implies, to the particular impact of Petrarch's Canzoniere on the works of other authors, then there must be elements in Petrarch's text and in the writings of his poetic followers that distinguish them from non-Petrarchan works. In order to identify these distinctive elements in Italian poetry, it may be useful to complete a contrastive analysis in which a target group of Petrarchan poems is compared to a comparison group of poems that are undoubtedly non-Petrarchan. Texts that can be considered to be definitely non-Petrarchan would pre-date the appearance of Petrarch's Canzoniere. ${ }^{6}$

Given the lack of research on the impact of different Zeta variants on contrastive analyses of poetry, four contrastive text analyses were carried out. Each one used a different variant of Zeta. ${ }^{7}$ The four resulting word lists were then compared $^{8}$ in order to create a list of overlapping distinctive elements. After a general review, the most striking elements were examined in more detail within their respective contexts by using collocation analyses. To this end, I used the tool TXM (Heiden et al. 2010).

\section{Corpus}

The corpus consisted of 55 different Italian collections of poems that dated mainly from the 14th, 15th or 16th centuries. It contained two parts: the target included 51 poetry collections $(10,212,741$ characters in total) in which researchers had been able to show Petrarch's influence. ${ }^{9}$ The comparison part, on the other hand, included nearly all of the Italian love poetry that appeared before Petrarch's Canzoniere (four collections of poetry or 680,707 characters in total). Although the size of each part, thus, differed, the corpus reflected the actual literary-historical state of affairs: the number of collections of love

\footnotetext{
5 Several works do, however, deal with the digital analysis of poetry (see, for example, Hoover 2008; Navarro-Colorado 2018a; Navarro-Colorado 2018b).

6 Even before the appearance of Petrarch's Canzoniere, Italian love poetry was astonishingly varied. For an overview, see Friedrich 1964, pp. 1-156.

7 These variants were "Craig's Zeta" and "Eder's Zeta" (both included in stylo) and "dd2" and "sd2". The latter two variants were developed by CLiGS and had achieved remarkable results in tests on prose and drama corpora (Schöch et al. 2018). To perform the contrastive analyses, "dd2" and "sd2" were also implemented with stylo. The code is available at http://dx.doi.org/10.20375/ 0000-000E-8B18-B.

8 For the comparison, I used the tool Multiple List Comparator (MLC 2020).

9 These collections were identified with the assistance of the research literature on Petrarchism, in particular Hempfer et al. 2005, pp. 24-76.
} 


\begin{tabular}{lccc}
\hline Part & Type of poetry & \# of collections & \# of characters \\
\hline Target part & Petrarchan & 51 & $10,212,741$ \\
Comparison part & Pre-Petrarchan & 4 & 680,707 \\
Total & & 55 & $10,893,448$ \\
\hline
\end{tabular}

Table 1: Overview of the corpus

poetry published since Petrarch's Canzoniere greatly exceeds the number of such collections published earlier. All but one of the texts in the corpus ${ }^{10}$ were based on scholarly editions produced by a reputable editor and publisher. The digital versions of these editions are available in the Biblioteca Italiana (BI 2020) digital library. In all of these texts, the following items were removed: punctuation marks, page and line numbers, footnotes, endnotes, headings, title pages, forewords, epilogues and any other comments. Moreover, passages explicitly identified as prose texts (for example, dedications, comments and authors' introductions) were deleted, and all majuscules were converted to minuscules. Otherwise, the corpus was not harmonised any further at a linguistic level. Each collection of poems was saved as a plain text file with UTF-8 encoding. ${ }^{11}$ This led to the following corpus (see Table 1).

\section{Contrastive Analysis of Petrarchan and Pre-Petrarchan Poetry}

Four contrastive analyses-i.e. one analysis for each of the four Zeta variantswere conducted on the Petrarchan target and the pre-Petrarchan comparison part. This resulted in four word lists.

The comparison of these four lists revealed 802 words that were preferred in the Petrarchan target. ${ }^{12}$ Among these distinctive words, some semantic fields stood out, as can be seen in Table 2 .

The semantic fields in the Petrarchan target part suggested essential aspects of Petrarchism.

\subsection{The Motif of Sweetness as an Allusion to Dolce Stil Novo}

The occurrence of words from the semantic field of sweetness among the preferred terms refers back to the pre-Petrarchan poetry of Dolce stil novo. The latter is also reflected in co-occurring expressions from various other semantic fields, for example, visual perception (see Section 6.7.1). Aside from expressions related to sweetness, other elements of Dolce stil novo can be identified in the Petrarchan target; this relates especially to the idealisation of the beloved. In the poetry of Dolce stil novo, the beloved is idealised based on a concept of

\footnotetext{
${ }^{10}$ The collection in question is Zaccagnini et al. 1915.

${ }^{11} \mathrm{~A}$ detailed list of all the poetry collections included in the corpus is available at http://dx.doi.org/ 10.20375/0000-000E-8B17-C.

${ }^{12}$ For the complete list of words, see http://dx.doi.org/10.20375/0000-000E-8B1A-9.
} 


\begin{tabular}{|c|c|}
\hline Semantic Field & Words \\
\hline Bitterness & amaro \\
\hline \multicolumn{2}{|l|}{ Character traits } \\
\hline Cruelty & crudel \\
\hline Grace & pietade, pietoso \\
\hline Gracefulness & grazia \\
\hline Gravity & grave, gravi \\
\hline Honour & onor, onora, onorata, valor \\
\hline Humility & umil \\
\hline Ingenuity & ingegno \\
\hline Misery & miser, misera, miseri, misero \\
\hline Nobility & nobil \\
\hline Piety & pio \\
\hline Purity & casto, pure, puro \\
\hline Value & virtute \\
\hline Coldness & freddo, gelo, ghiaccio \\
\hline Divinity and heavenliness & $\begin{array}{l}\text { ciel, cielo, divin, divina, divino, santa, santi, } \\
\text { santo }\end{array}$ \\
\hline Fate and glory & $\begin{array}{l}\text { corona, destino, eterna, fama, fortuna, lauro, } \\
\text { orte }\end{array}$ \\
\hline \multicolumn{2}{|c|}{ Feelings and emotional states } \\
\hline Anger and hatred & ira, irato, odio \\
\hline Desire & brama, bramo \\
\hline Fear & teme, temer, timore \\
\hline Indignation & sdegno \\
\hline Grief and sorrow & $\begin{array}{l}\text { affanni, fame, lacrime, lagrime, lamenti, } \\
\text { piante, pianti, piant, tristi, tristo }\end{array}$ \\
\hline Happiness & beata, beati, beato, lieto, lieta, serena, sereno \\
\hline Hope & speme, sperar \\
\hline Longing & desio, desir, desire, disiri \\
\hline Love and affection & affetto, amori, amorose \\
\hline Pain & dolor, duol, duole, duolo \\
\hline Pride & fiera, fiere, fiero \\
\hline Revenge & vendetta \\
\hline Solitude & sol, sola, soli \\
\hline Tiredness & stanca, stanco \\
\hline Fire & $\begin{array}{l}\text { arder, ardor, ardore, faville, fiamma, } \\
\text { fiamme, infiamma }\end{array}$ \\
\hline
\end{tabular}




\begin{tabular}{ll}
\hline Semantic Field & Words \\
\hline Nature & acqua, acque, bosco, colli, erba, erbe, fiori, \\
& fiorito, fiume, fiumi, flora, fonte, fonti, legno, \\
& luna, mar, monte, monti, nido, nubi, notte, \\
& pietra, pioggia, rio, sasso, scoglio, selva, \\
& seme, venti, vento \\
Physicality and humanity & \\
Blood & sangue \\
Body parts and Physicality & braccio, chioma, corpo, fronte, grembo, man, \\
& mano, morso, occhio, passo, passi, petti, \\
Humanity & petto, piede, piedi, sen, seno, volto \\
Poetry and language & \\
Language & lingua, lingue \\
Meaning & senso \\
Muse & musa \\
Rhymes & rime \\
Speaking & parlar \\
Style & stil \\
Verses & versi \\
Words & parole \\
Reign & mercede, regni, regno, servi \\
Sensory perception & \\
Colours & bianco, bianche, biondo, bionde, colori, oro, \\
Darkness & verde \\
Light & tenebre \\
Odour & luce, lucenti, lume, raggi, raggio, riluce, \\
Sign & splende, splendor \\
Sound & odor \\
taste & segni, segno \\
Vision & suon, suona, udite \\
Voice & amaro, crud \\
Soul & mirar, mirando, vedo, vedrai, vedrá, veggia, \\
Theetness & veggio, visto \\
War & voce, voci \\
\hline & alma, anima, animo, aura, spirti, spirto \\
& dolcezza, dolci, soave, soavi \\
& memoria, oblio, pensier, pensieri, pensiero \\
& \\
&
\end{tabular}

Table 2: Notable semantic fields in the Petrarchan target 
gentilezza (spiritual nobility), a particular aptitude for love that is based not on the speaker's origins or social status but on his soul alone. This idealisation based on gentilezza leads the lyric's speaker to ascribe angelic qualities to the beloved, as is illustrated in Section 6.5. ${ }^{13}$

\subsection{Love Expressed as War}

Expressions from the semantic field of war are also present among the Petrarchan target's distinctive words. This suggests that in Petrarchan poetry, love can be expressed as a form of war, as has previously been pointed out in the literary research (Hoffmeister 1973, p. 25).

\subsection{Duality as a Stylistic Device}

The co-occurrence of expressions from sharply contrasting semantic fields attests to the high number of dualities often found in Petrarchan poetry. The contrasts of coldness/fire and bitterness/sweetness are a clear indication of this; a co-occurrence analysis of words from the semantic field of coldness highlights the first example further. Among the words with the highest co-occurrence scores $^{14}$ are a considerable number from the semantic field of fire. The 18 words with the highest co-occurrence scores for "fredd." ${ }^{* 15}$ (cold) are listed in Table 3.

\subsection{Dolendi Voluptas}

The presence of opposing forces is also clear in the semantic fields of love and pain, which occur together quite often. This points to the role of dolendi voluptas, a concept that scholars consider typical of Petrarchan poetry. This can be seen in the terms co-occurring with "dolo.*" (pain) in Table 4. These words, which include "core" (heart) and "gioia" (joy), at once capture the opposition between pain and pleasure and refer to love, which is symbolised by the heart.

\subsection{Idealisation of the Beloved as a Superhuman Being}

The idealisation of the beloved, another typical element of Dolce stil novo, is illustrated by the co-occurrence of words from the semantic fields of divinity and heavenliness on the one hand and humanity on the other. Table 5 shows words co-occurring with "divin.*” (the divine). Here divinity is often detected among humanity through the stylisation of the beloved.

\footnotetext{
${ }^{13}$ For an overview of Dolce stil novo, see Pirovano 2014.

${ }^{14}$ The co-occurrence score indicates the degree of specificity of the co-occurrence of two words. See Lafon 1980 for the mathematical background.

${ }^{15}$ This is a search query for words that start with "fredd" and can have any number of characters. The dot (“.”) stands for any character (except the space character); the asterisk (“*”) indicates that the directly preceding character can occur any number of times (or even not at all). For a clear introduction to the functions and search syntax of TXM, see Schöch 2020.
} 


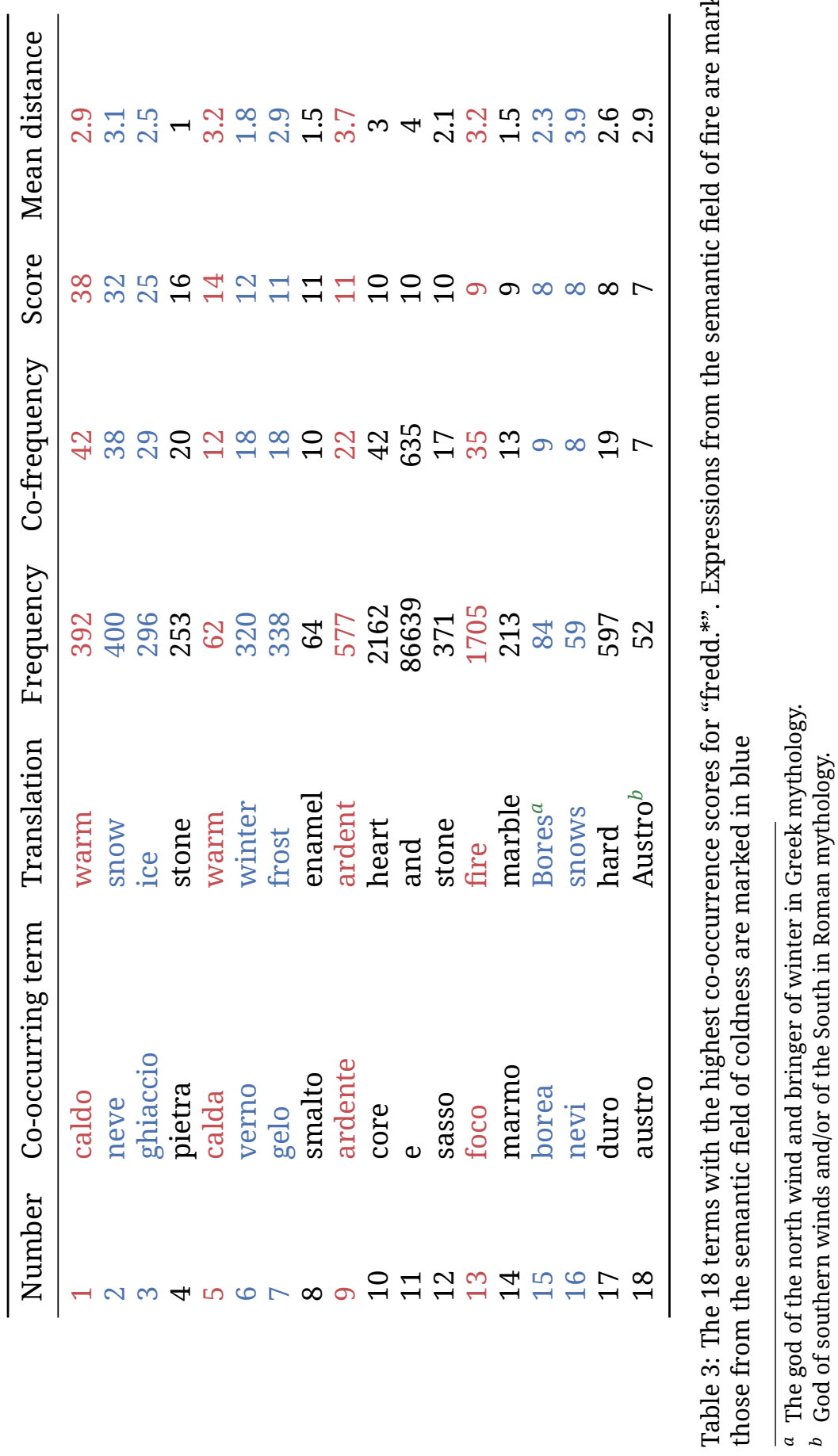


サ ஸ ஸ் ம்

ชृ

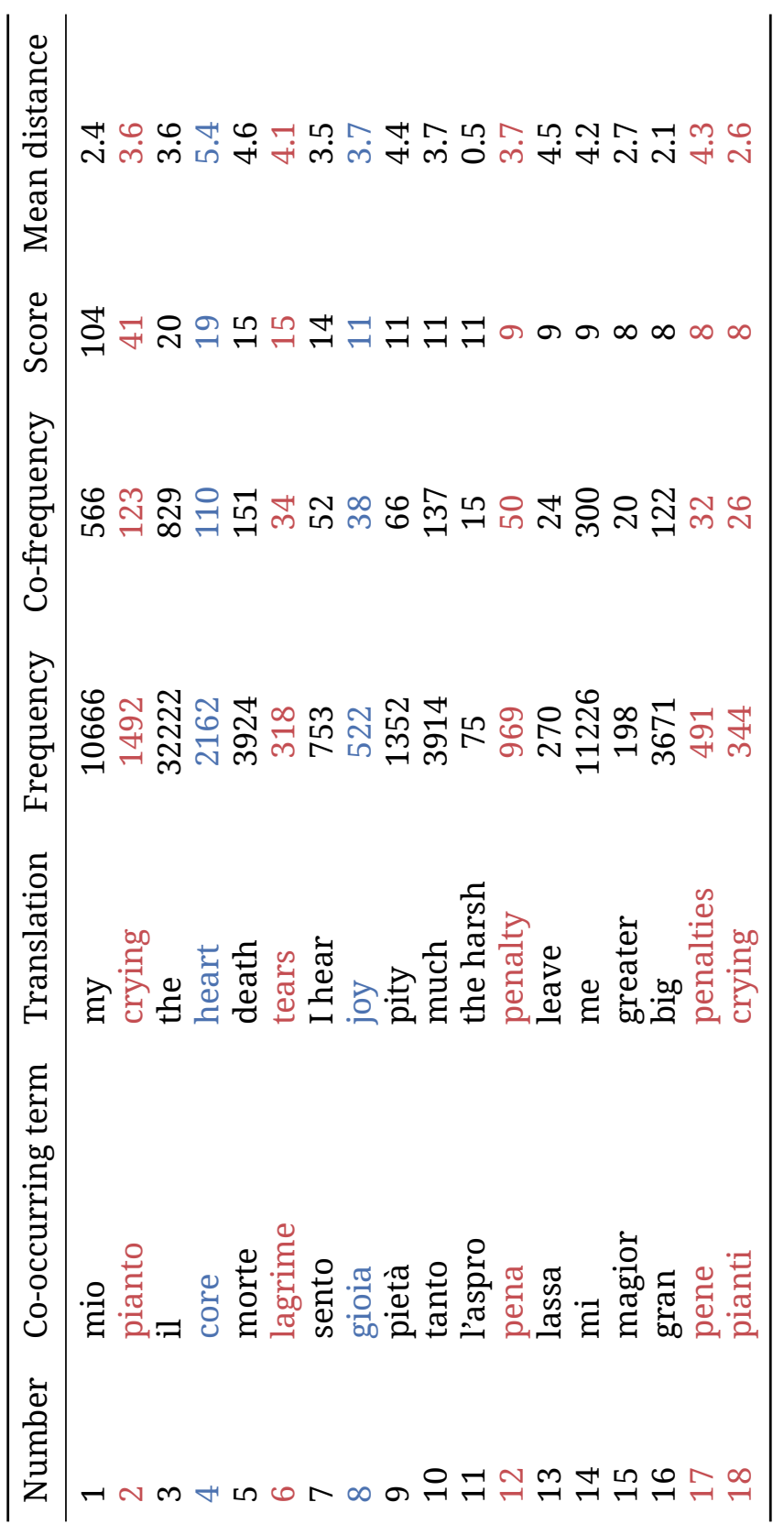

ป.

*

$\frac{0}{\frac{0}{0}}$

iั

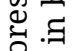

记

氖

ఫ ह

苞

○े

○

के

.

르

온

의

为

¿ ฮ્

क्ष

$\stackrel{\infty}{2}$

气 ह્ટّ

$\ddot{4}$

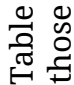




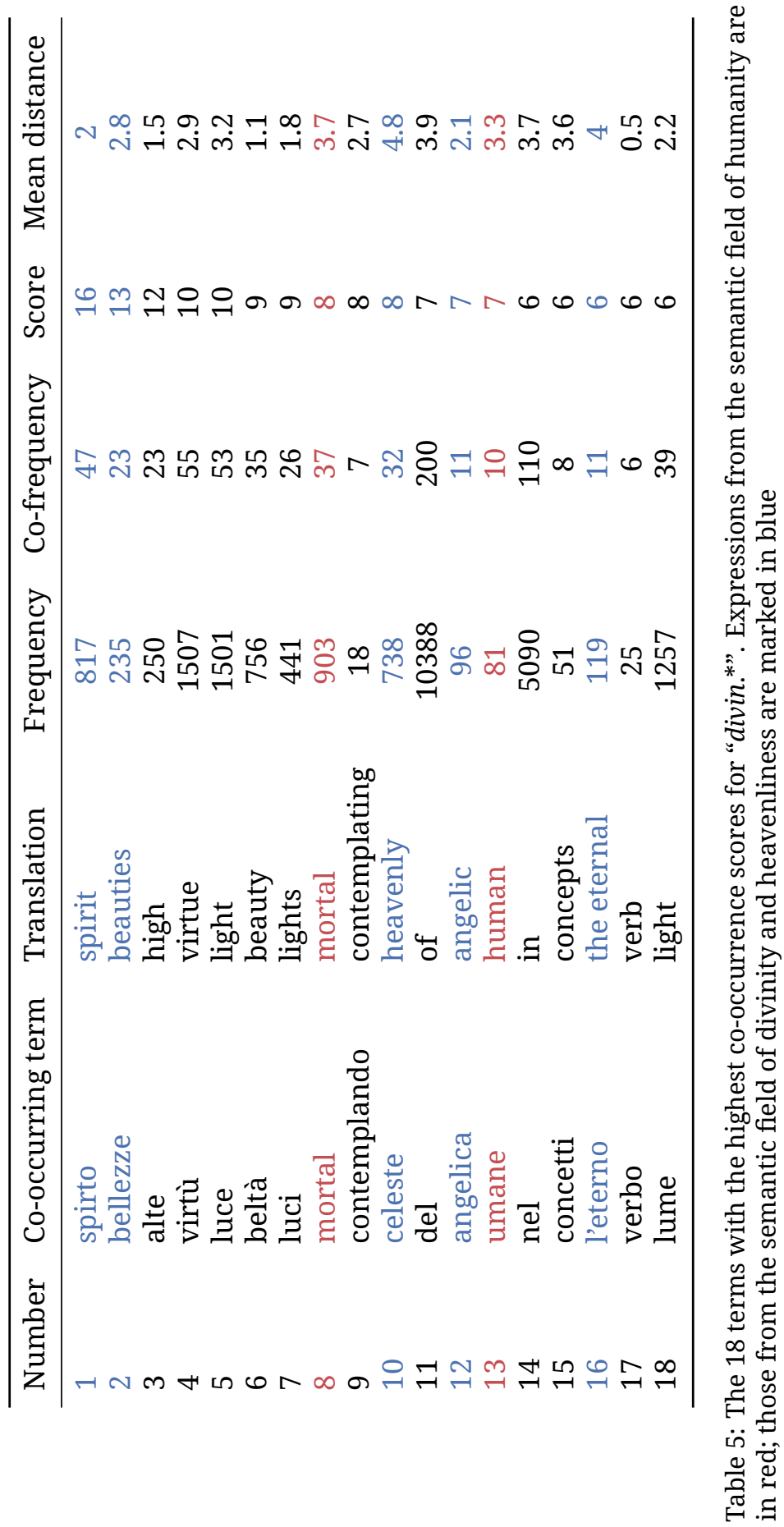


Among these co-occurring terms, "angelica" (angelic) is particularly interesting because it evokes the concept of "donna angelicata" (angelic woman). The latter is relevant not only to Dolce stil novo poetry but also to Dante's Vita Nova.

\subsection{Subjectivity as a Key Theme in Petrarchan Poetry}

While the observations above broadly confirm issues already noted in the literary research, contrastive analyses reveal other elements of Petrarchism that have received less attention. Of particular significance are the four semantic fields with the highest numbers of distinctive words: character traits; feelings and emotional states; nature; and sensory perception. The first two fields have a highly subjective focus: the speaker's preoccupation with the beloved and her character traits and features that has ultimately led him to declare his feelings. This leads to a detailed characterisation of the beloved and, at the same time, reveals the great range of emotional states of the lyric's "I". The encounter between the "I" and the beloved highlights one of the characteristic dichotomies of Petrarchan poetry. This is expressed in different ways, as the large number of expressions from the semantic fields "character traits" and "feelings and emotional states" demonstrates. As the contrastive analysis shows, the detailed exploration of the soul of the "I" and his various emotional states which is achieved in Petrarch's Canzoniere (Geyer 2009) proves to be characteristic of Italian Petrarchan poetry more generally.

\subsection{Sensory Perception as a Key Theme in Petrarchan Poetry}

In the corpus studied, the first-person speaker's exploration of his own subjectivity takes place especially in the realm of sensory perception. In this context, visual perception has an important role, as is particularly striking in two semantic fields: the perception of nature and the perception of the human body. Although Italian poetry employed visual perception as a means of approaching the beloved even before Petrarch (Zeiner 2006), both the importance and complexity of this perception reach a new level in Petrarchan poetry.

\subsubsection{Visual Perception as the Preferred Approach to the Beloved}

In this regard, the eyes have special significance as both a symbol of visual perception and a characteristic feature of the beloved. This can be seen from the many expressions in which composites of "occh.*" (eye) are among the most common co-occurring terms. These patterns characterise visual experience, and thus, sensory perception in general as an important aspect of love. They are exemplified in the 18 terms with the highest co-occurrence scores for "amor." (love) (Table 6).

The eyes are also related to beauty and female beauty in particular. This is made clear by the most common co-occurring terms for "bell.*" (beauty) in Table 7. 


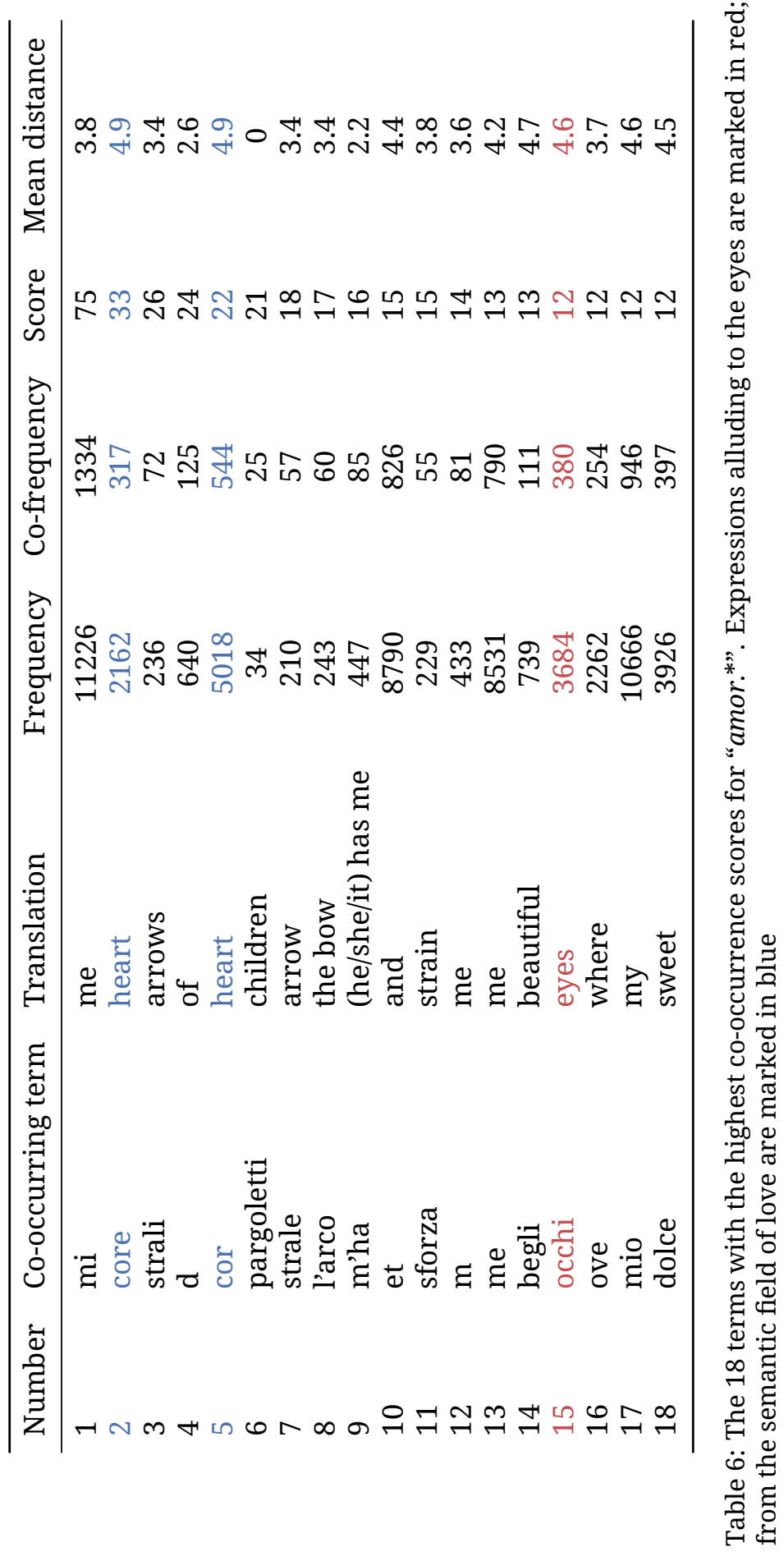




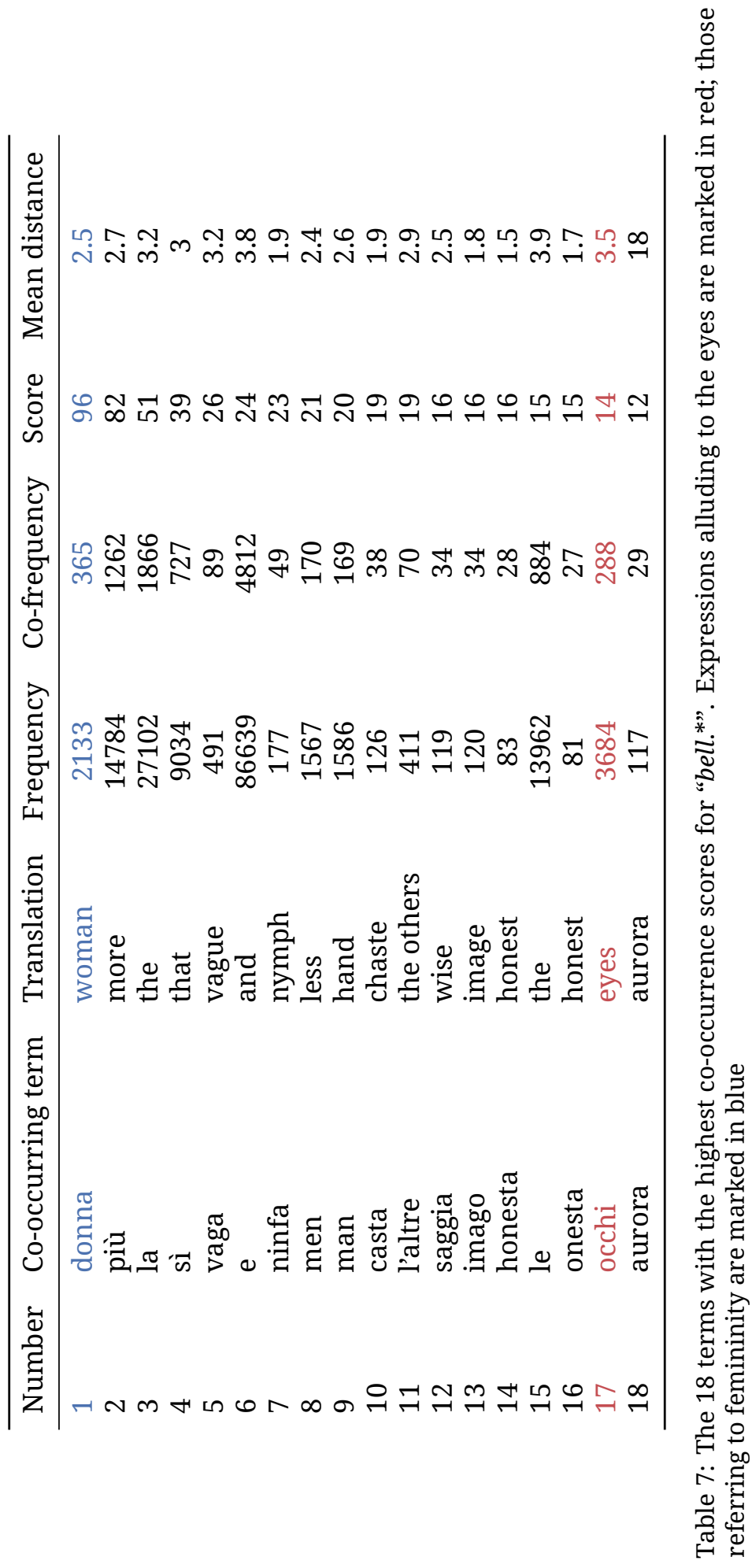


The eyes are connected with beauty in two ways: they are sensory organs for perceiving beauty, and they are body parts which themselves contribute to the beauty of the beloved.

Moreover, the eyes frequently appear together with expressions from the semantic field of sweetness (for example "dolc.*" or "soav.*”), which can be understood as a reference to Dolce stil novo (see Section 6.1).

\subsubsection{Visual Perception as the Basis for the Idealisation of the Beloved}

Furthermore, the eyes appear in the context of different parts of the body, including the hair ("chiom.*”), forehead ("front.*”), feet ("pied."”), breasts ("seno") and face ("volt."). ${ }^{16}$ As such, the eyes are not only relevant as organs that are physical objects but they are also the preferred way of perceiving the body of the beloved. This visual perception of the physical beauty of the beloved is the starting point for her idealisation, which is expressed through different semantic fields. The latter include, on the one hand, many terms from the semantic field of light, for example, "luc.*” (light), "lum.*” (light), "ragg.*” (ray), "riluc.*” (shining), "splend."” (splendid). ${ }^{17}$ On the other, they extend to expressions from the semantic field of fire, for example, "ard.*” (burn) and "fiamm."” (flame). ${ }^{18}$ Based on this idealisation, the beloved attains the divine qualities typically celebrated in the poetry of Dolce stil novo. This can be seen from the co-occurring terms for "uman.*" (human) listed in Table 8.

This visually perceived semblance ("sembiante", "forma") reveals the beloved to be a creature who is equally human ("petti", "corpo") and divine ("angelo", "divin"). ${ }^{19}$

The analysed corpus, thus, highlights three essential aspects of the depiction of love in Italian Petrarchism: the prevalence of visual perception in general; the use of idealising perception in the style of gentilezza in Dolce stil novo; and the resulting conception of the woman as both a human and divine creature. The common basis of all three aspects is vision, as evidenced by the co-occurring terms for "visio.*" (vision) listed in Table 9. These terms cover expressions from a range of semantic fields that include the following: divinity and heavenliness, humanity and sweetness.

\footnotetext{
${ }^{16}$ The associated tables can be accessed at https://repository.de.dariah.eu/1.0/dhcrud/21.11113/ 0000-000E-8AD3-8, https://repository.de.dariah.eu/1.0/dhcrud/21.11113/0000-000E-8AD2-9, https: //repository.de.dariah.eu/1.0/dhcrud/21.11113/0000-000E-8AD7-4, https://repository.de.dariah. eu/1.0/dhcrud/21.11113/0000-000E-8ADA-1, https://repository.de.dariah.eu/1.0/dhcrud/21.11113/ 0000-000E-8ADC-F.

${ }^{17}$ The associated tables can be accessed at https://repository.de.dariah.eu/1.0/dhcrud/21.11113/ 0000-000E-8AD5-6, https://repository.de.dariah.eu/1.0/dhcrud/21.11113/0000-000E-8AD6-5, https: //repository.de.dariah.eu/1.0/dhcrud/21.11113/0000-000E-8AD8-3, https://repository.de.dariah. eu/1.0/dhcrud/21.11113/0000-000E-8AD9-2, https://repository.de.dariah.eu/1.0/dhcrud/21.11113/ 0000-000E-8ADB-0.

${ }^{18}$ The associated tables can be accessed at https://repository.de.dariah.eu/1.0/dhcrud/21.11113/ 0000-000E-8AD1-A, https://repository.de.dariah.eu/1.0/dhcrud/21.11113/0000-000E-8AD4-7.

${ }^{19}$ Similarly, the co-occurring terms for "divin.*” also refer to the divine and human dimensions of the beloved (see Section 6.5.)
} 


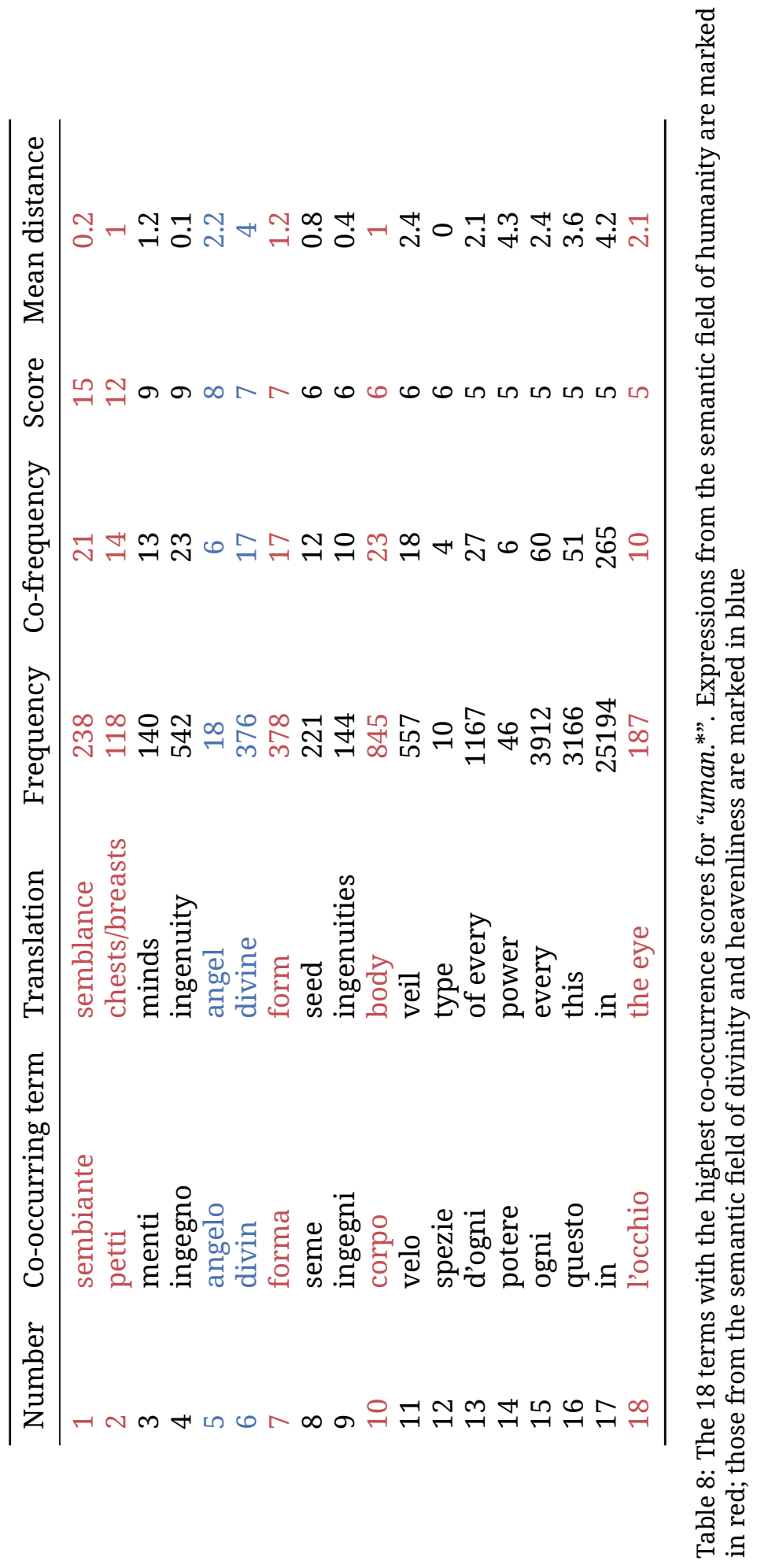




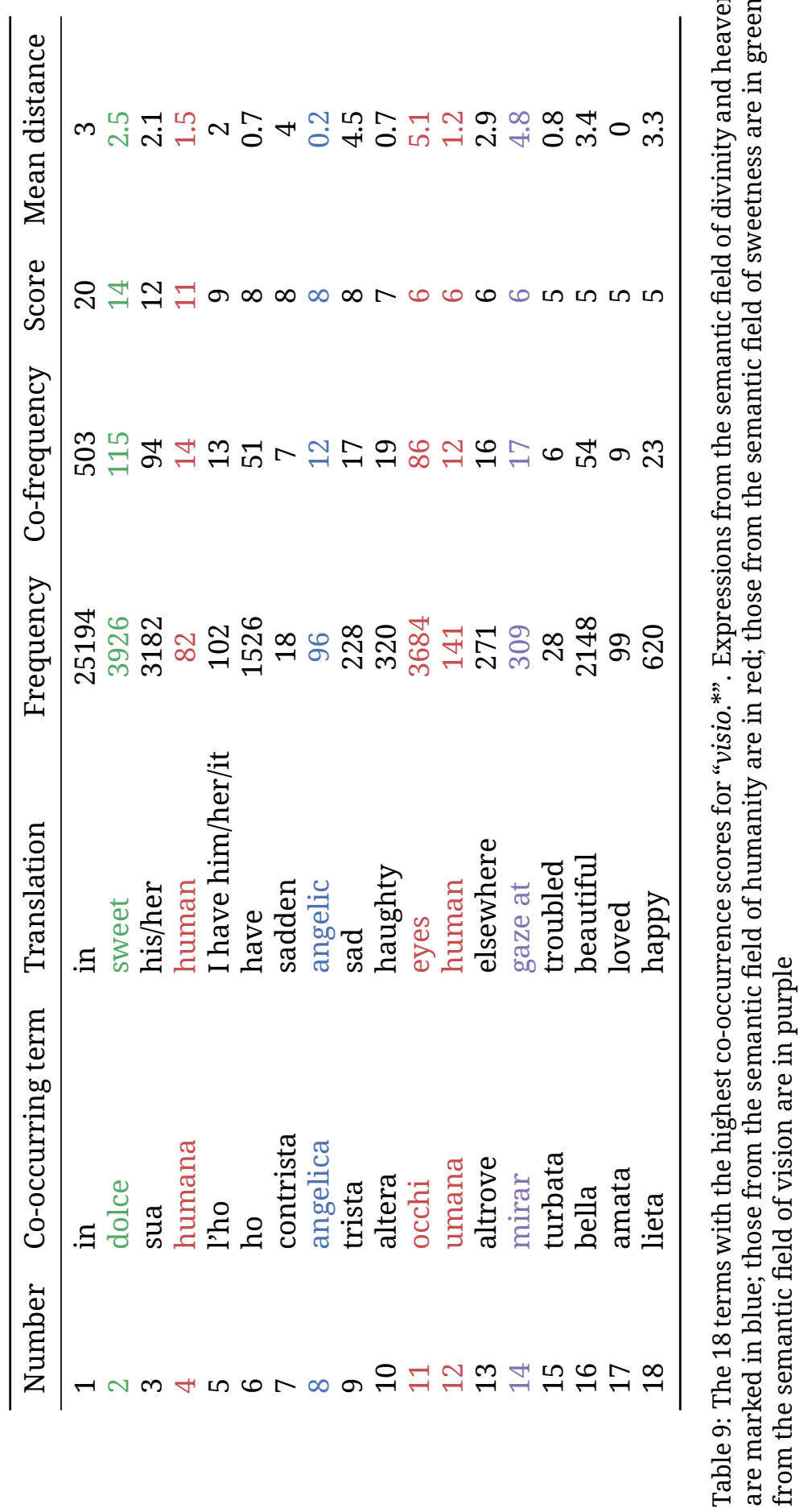




\subsubsection{Visual Perception as the Basis for Petrarchan Poetry}

The significance of visual perception for Petrarchism is also evident from the expressions co-occurring with one of poetry's most characteristic formal elements: verse ("vers.*”). These co-occurrences suggest important motifs in Petrarchan love poetry, as Table 10 demonstrates.

The 18 terms with the highest co-occurrence scores reflect essential elements of Petrarchan poetry, namely subjectivity ("miei", "mei"), emotionality ("lagrime", "pianto"), physicality ("sangue", "vena"), visual perception ("occhi”), allusions to Dolce stil novo ("dolci") and nature ("fiume", "fiori"). The reference to prose ("prosa", "prose") is also noteworthy. On the one hand, it highlights the prose dimension while on the other, it creates a contrast with the language of verse ("versi"). In this way, it also illustrates the stylistic device of duality (see Section 6.3).

\subsubsection{Nature as a Key Theme in Petrarchan Poetry}

Significantly, individual expressions from the semantic field of nature do not usually occur in isolation in the corpus studied. Rather they are accompanied by other expressions from the same semantic field. This suggests that Petrarchan poetry does not use nature as a mere point of reference but instead sketches natural panoramas by combining different expressions from this semantic field. This can be seen, for example, from the terms co-occurring with "bosc.*” (forest) listed in Table 11.

\subsection{Unassignable Co-Occurrences}

In addition to clearly assignable co-occurrences, Tables 3 to 11 also include expressions that cannot be easily attributed to a specific semantic field. A comparison of these words reveals two patterns. Firstly, among the expressions that cannot be clearly assigned are words that lack any lexical meaning and instead have a grammatical function. These include articles, ${ }^{20}$ conjunctions, ${ }^{21}$ demonstrative pronouns ${ }^{22}$ and prepositions ${ }^{23}$ that is, basically function words whose significance for stylometric analyses has already been demonstrated (Argamon et al. 2005; Kestemont 2014). Secondly, the tables feature quite a large number of object pronouns and possessive pronouns in the first-person singular. ${ }^{24}$ These pronouns reflect at a grammatical level the intense involvement of the lyrical "I" with the beloved, which indirectly leads to a preoccupation with his own emotional state. As such, they highlight the highly subjective dimension of Petrarchan love poetry, as outlined in Section 6.6. Notwithstanding these

\footnotetext{
${ }^{20}$ These are "il" in Table 4, "l”'("eterno") in Table 5, "la" and "le" in Table 7 and "i" in Tables 10 and 11.

${ }^{21}$ These are "e" in Tables 3, 7 and 11 and "et" in Table 6.

22 These are "questo" in Table 8 and "questi" in Table 11.

${ }^{23}$ These are as "del" and "nel" in Table 5, "d" in Table 6, "d"'("ogni”) in Table 8 and "in” in Tables 8 and 9.

${ }^{24}$ These are "mio" and "mi” in Tables 4 and 6, “m”'(ha”), "m” and “me” in Table 6, "l”'("ho”) in Table 9 and "miei" and "mei" in Table 10.
} 


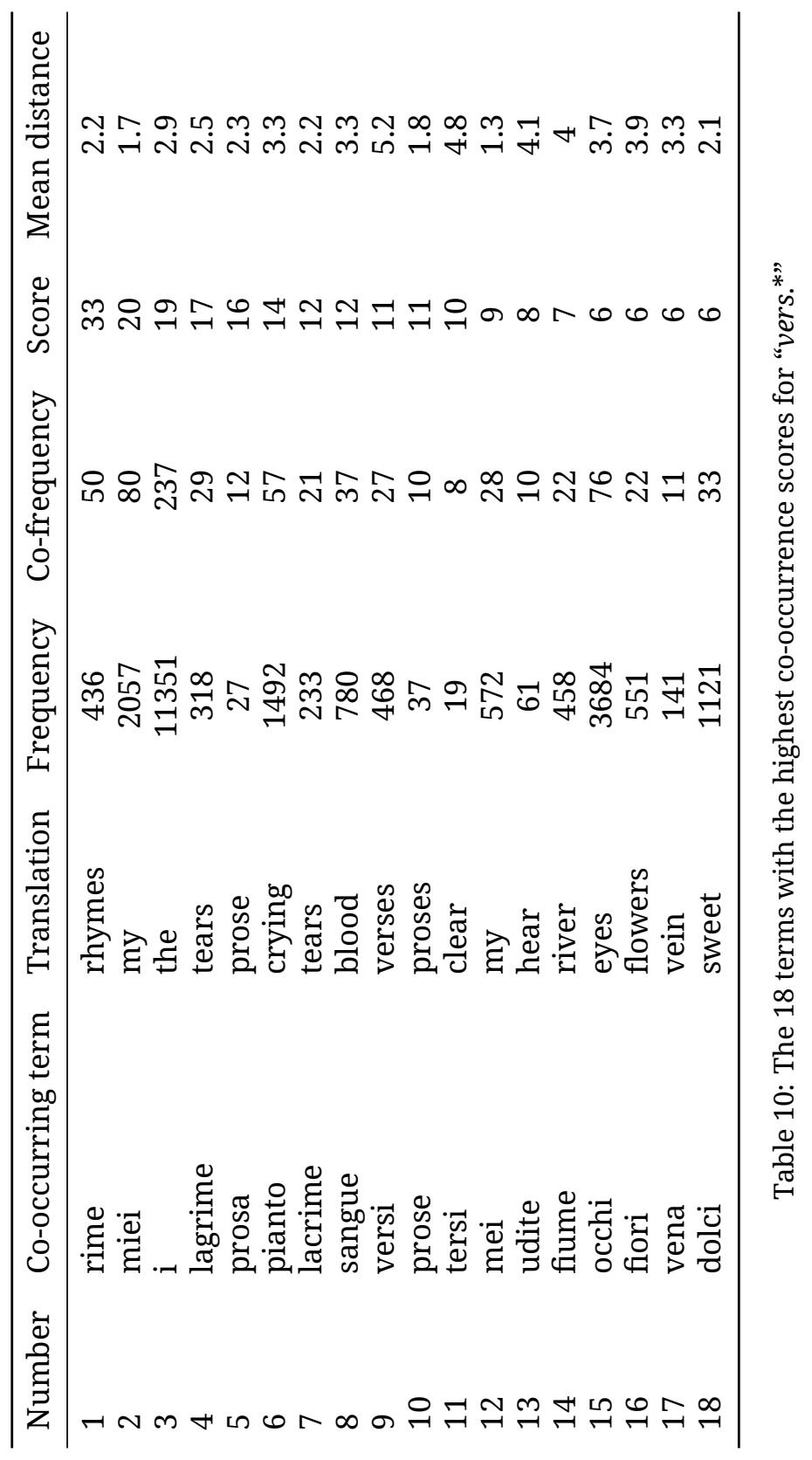




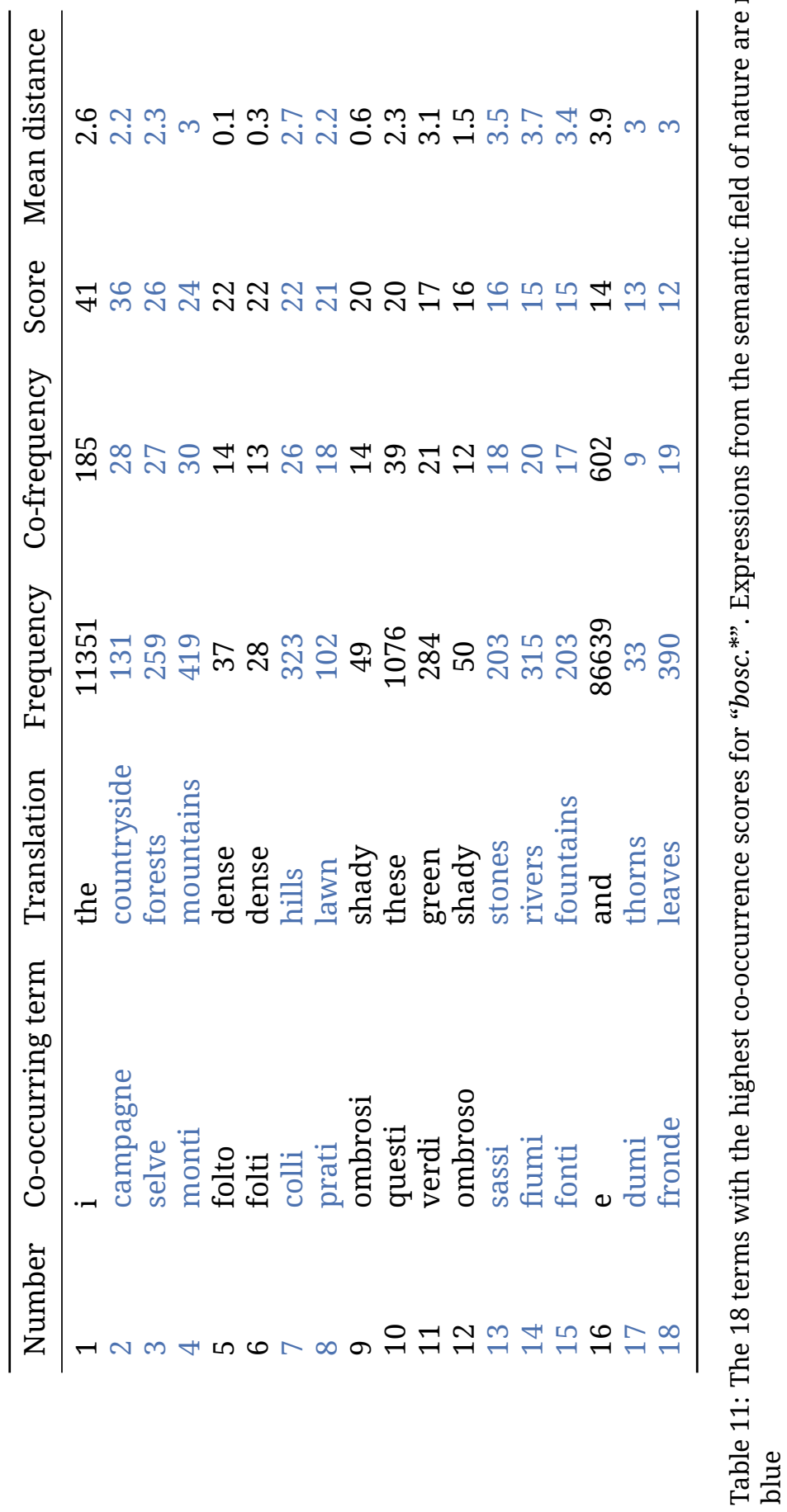


function words, the majority of the co-occurring terms listed in Tables 3 to 11 have a lexical meaning. In other words, at least the items examined with the highest co-occurrence scores are comparatively highly interpretable. From a literary studies perspective, this is encouraging as it suggests that a co-occurrence analysis may be a useful addition to contrastive analyses. ${ }^{25}$

\subsection{Conclusion}

The aim of the present study was to identify distinctive motifs in the poetry of Italian Petrarchism through a combination of contrastive stylometric analyses and co-occurrence analyses of a corpus of Italian poetry. In this way, I sought to contribute to a comprehensive typology of Petrarchan motifs. The chosen methodology enabled me to uncover distinctive elements in the Petrarchan target on whose basis characteristic semantic fields could be identified.

Based on these semantic fields and their respective co-occurring terms, I found evidence of not only some aspects of Petrarchism already observed in the literary research but also elements that had hitherto been less prominent in that discourse. Of particular note was the prevalence of visual perception, which proved to be fundamental to three themes: the conception of love by the lyric's first-person speaker; the depth of his subjectivity; and the notion of poetry itself. Vision may, thus, be considered an important element in a considerable number of Italian Petrarchan poetry collections.

Nevertheless, the present study can only serve as a first step in creating a comprehensive inventory of Petrarchan motifs. To gain a more complete picture of Petrarchism, it may be helpful to conduct similar analyses of Petrarchan corpora in other languages such as German, English and Spanish. After all, if there is one point of consensus in the literary research on Petrarchism, it is Petrarch's far-ranging international reception. In exploring this topic, digital methods will certainly be of great use.

\section{References}

Argamon, Shlomo and Shlomo Levitan (2005). "Measuring the usefulness of function words for authorship attribution". In: Proceedings of the 2005 ACH/ALLC Conference. Victoria: University of Victoria, pp. 33-34. URL: https://citeseerx. ist.psu.edu/viewdoc/download? doi=10.1.1.71.6935\&rep=rep1\&type=pdf (visited on 11/15/2020).

Baldacci, Luigi (1957). Il Petrarchismo Italiano Nel Cinquecento. Milano, Napoli: Ricciardi.

Bernsen, Michael and Bernhard Huss, eds. (2011). Der Petrarkismus - ein europäischer Gründungsmythos. Göttingen: V\&R. URL: http://hdl.handle.net/20. $500.11811 / 544$.

BI (2020). Biblioteca Italiana. URL: http://www.bibliotecaitaliana.it/ (visited on $11 / 15 / 2020)$.

\footnotetext{
${ }^{25}$ Schöch et al. (2018) illustrate the comparatively high interpretability of word lists generated on the basis of Zeta.
} 
Burrows, John (2007). "All the Way Through: Testing for Authorship in Different Frequency Strata”. In: Literary and Linguistic Computing 22.1, pp. 27-47. DOI: 10.1093/llc/foii067.

Chines, Loredana, Floriana Calitti, and Roberto Gigliucci, eds. (2006). Il petrarchismo: Un modello di poesia per l'Europa. Roma: Bulzoni.

Eder, Maciej, Jan Rybicki, and Mike Kestemont (2016). "Stylometry with R: A Package for Computational Text Analysis”. In: The R Journal 8.1, pp. 107-121. DoI: 10.32614/RJ-2016-007.

Fornasiero, Serena (2001). Petrarca: guida al Canzoniere. Roma: Carocci.

Forster, Leonard W. (1963). "European Petrarchism as Training in Poetic Diction". In: Italian Studies 18.1, pp. 19-32. DoI: 10.1179/its.1963.18.1.19.

Friedrich, Hugo (1964). Epochen der italienischen Lyrik. Frankfurt am Main: Klostermann.

Geyer, Paul (2009). "Petrarcas Canzoniere als Bewusstseinsroman”. In: Petrarca und die Herausbildung des modernen Subjekts. Ed. by Paul Geyer and Kerstin Thorwarth. Göttingen: V\&R, pp. 109-156.

Heiden, Serge, Jean-Philippe Magué, and Bénédicte Pincemin (2010). “TXM: Une plateforme logicielle open-source pour la textométrie-conception et développement”. In: 10th International Conference on the Statistical Analysis of Textual Data-JADT 2010. Vol. 2. Milano: LED, pp. 1021-1032. URL: https: //halshs.archives-ouvertes.fr/halshs-00549779/fr/ (visited on 11/15/2020).

Hempfer, Klaus W. (1987). "Probleme der Bestimmung des Petrarkismus. Überlegungen zum Forschungsstand”. In: Die Pluralität der Welten: Aspekte der Renaissance in der Romania. Ed. by Wolf-Dieter Stempel and Karlheinz Stierle. München: Fink, pp. 253-277.

Hempfer, Klaus W., Gerhard Regn, and Sunita Scheffel, eds. (2005). PetrarkismusBibliographie, 1972-2000. Stuttgart: Steiner.

Hoffmeister, Gerhart (1973). Petrarkistische Lyrik. Stuttgart: Metzler.

Hoover, David L. (2008). "Searching for style in modern American poetry". In: Directions in Empirical Literary Studies. Linguistic Approaches to Literature, 5. Ed. by Sonia Zyngier, Marisa Bortolussi, Anna Chesnokova, and Jan Auracher. Amsterdam: John Benjamins Publishing Company, pp. 211-227. DoI: 10.1075/ lal.5.18hoo.

Kestemont, Mike (2014). "Function Words in Authorship Attribution. From Black Magic to Theory?” In: Proceedings of the 3rd Workshop on Computational Linguistics for Literature (CLFL). Gothenburg: Association for Computational Linguistics, pp. 59-66. DoI: 10.3115/v1/W14-0908.

Lafon, Pierre (1980). "Sur la variabilité de la fréquence des formes dans un corpus”. In: Mots 1, pp. 127-165. Dor: 10.3406/mots.1980.1008.

MLC (2020). Multiple List Comparator. URL: http :// www . molbiotools .com/ listcompare.html (visited on 11/15/2020).

Morales Saravia, José (1998). "Vanitas y petrarquismo en el soneto XXIII de Garcilaso de la Vega”. In: Iberoromania 47, pp. 47-71. DoI: 10.1515/iber.1998. 1998.47.47.

Navarro-Colorado, Borja (2018a). "A metrical scansion system for fixed-metre Spanish poetry”. In: Digital Scholarship in the Humanities 33.1, pp. 112-127. DOI: 10.1093/llc/fqx009. 
Navarro-Colorado, Borja (2018b). “On Poetic Topic Modeling: Extracting Themes and Motifs From a Corpus of Spanish Poetry”. In: Frontiers in Digital Humanities 5, pp. 1-12. DoI: 10.3389/fdigh.2018.00015.

Pirovano, Donato (2014). Il Dolce stil novo. Roma: Salerno Editrice.

Pyritz, Hans (1963). Paul Flemings Liebeslyrik: Zur Geschichte des Petrarkismus. Göttingen: V\&R.

Regn, Gerhard (1993). "Systemunterminierung und Systemtransgression. Zur Petrarkismus-Problematik in Marinos Rime amorose (1602)”. In: Der Petrarkistische Diskurs: Spielräume und Grenzen. Ed. by Klaus W. Hempfer and Regn Gerhard. Stuttgart: Steiner, pp. 255-281.

Regn, Gerhard (2013). "Petrarkismus”. In: Historisches Wörterbuch Der Rhetorik Online. Ed. by Gert Ueding. Berlin: De Gruyter. Dor: 10.1515/hwro.

Santagata, Marco (1992). I frammenti dell'anima storia e racconto nel Canzoniere di Petrarca. Bologna: Il Mulino.

Schiffer, James (2000). “Shakespeare's Petrarchism”. In: Shakespeare's sonnets: Critical essays. Ed. by James Schiffer. New York: Garland, pp. 163-183.

Schöch, Christof (2017). Pyzeta. Python implementation of the Zeta score for contrastive text analysis. Version 0.3.0. URL: https://github.com/cligs/pyzeta (visited on 11/15/2020).

Schöch, Christof (2018). "Zeta für die kontrastive Analyse literarischer Texte”. In: Quantitative Ansätze in den Literatur- und Geisteswissenschaften. Ed. by Toni Bernhart, Marcus Willand, Sandra Richter, and Andrea Albrecht. Berlin, Boston: De Gruyter, pp. 77-94. Dor: 10.1515/9783110523300-004.

Schöch, Christof (2020). TXM-Tutorial. Figurenbeschreibungsprojekt, Zoom, Juli 2020. URL: https://christofs.github.io/txm-tutorial/\#/ (visited on 11/15/2020).

Schöch, Christof, Daniel Schlör, Albin Zehe, Henning Gebhard, Martin Becker, and Andreas Hotho (2018). "Burrows' Zeta: Exploring and Evaluating Variants and Parameter.” In: ADHO 2018. Book of Abstracts. URL: https : //dh2018.adho.org/burrows-zeta-exploring-and-evaluating-variants-andparameters/ (visited on 11/15/2020).

Warning, Rainer (1987). "Petrarkistische Dialogizität am Beispiel Ronsards". In: Die Pluralität der Welten: Aspekte der Renaissance in der Romania. Ed. by Wolf-Dieter Stempel and Karlheinz Stierle. München: Fink, pp. 327-358.

Zaccagnini, Guido and Amos Parducci (1915). Rimatori siculo-toscani del dugento. Bari: Laterza. URL: https://www.liberliber.it/online/autori/autori-r/rimatorisiculo-toscani-del-dugento/rimatori-siculo-toscani-del-dugento/ (visited on 11/15/2020).

Zeiner, Monika (2006). Der Blick der Liebenden und das Auge des Geistes. Die Bedeutung der Melancholie für den Diskurswandel in der Scuola Siciliana und im Dolce Stil Nuovo. Heidelberg: Winter. 